\title{
KUALITAS INTERNAL AUDITOR DAN BIAYA AUDIT DALAM PENENTUAN KUALITAS AUDIT
}

\author{
Dharma Dhatu \\ Patricia Diana * \\ Universitas Multimedia Nusantara, Jalan Scientia Boulevard, Gading, Serpong, Tangerang, Banten \\ *patricia@umn.ac.id
}

\author{
A R T I C L E I N F O \\ Article history: \\ Received January 13, 2020 \\ Revised June 3, 2020 \\ Accepted July 4, 2020 \\ Key words: \\ Auditor Internal Quality, Audit Fee, \\ Audit Quality \\ DOI: \\ https://doi.org/10.33508/jako.v12i2.2308
}

\begin{abstract}
A B S T R A C T
Objective of this studies is to explain effect of auditor internal quality and audit fee on audit quality. Data collected by questionnaires to auditors who working in Public Accounting Firm. The population of this study were public accountants working at Jakarta and Tangerang. Sample selection using convenience method and using primary data. Respondent of this study were auditors that have at least one year work experience and work as senior auditors and had carried out all of the audit process. 201 questionnaires distributed, but only 179 questionnaires returned and 101 questionnaires can be used for analyzed in this research using multiple linear regressions. The results of this study were (1) professionalism had significant effect on auditor audit quality, (2) audit risk had significant effect on audit quality, (3) time budget pressure had no effect on audit quality and (4) audit fee had significant effect on audit quality.
\end{abstract}

\begin{abstract}
A B S T R A K
Penelitian ini bertujuan untuk menjelaskan pengaruh keualitas internal auditor dan biaya audit terhadap kualitas audit. Pengumpulan data menggunakan kuesioner yang dibagikan kepada auditor di Kantor Akuntan Publik. Populasi dalam penelitian adalah eksternal auditor yang bekerja di Jakarta dan Tangerang dengan pemilihan sampel menggunakan convenon sampling. Data yang digunakan merupakan data primer dengan kriteria pemilihan sampel yaitu senior auditor yang memiliki pengalaman kerja minimal 1 tahun dan telah melaksanakan seluruh tahapan audit. Seusioner yang disistribusikan sebanyak 201 namun hanya 179 kuesioner yang kembali. Sesuai dengan kriteria pemilihan sampel, maka hanya 101 kuesioner yang dapat digunakan untuk analisa data. Teknik analisis yang digunakan adalah regresi linerar berganda. Hasil pengujian menunjukkan bahwa (1) profesionalisme tidak berpengaruh terhadap kualitas audit, (2) resiko audit tidak berpengaruh terhadapa kualitas audit, (3) tekanan anggaran waktu tidak berpengaruh terhadapa kualitas audit, dan (4) biaya berpengaruh signifikan terhadapa kualitas audit.
\end{abstract}

\section{PENDAHULUAN}

Laporan keuangan dipahami sebagai penyajian terstruktur dari posisi keuangan serta dapat menunjukkan kinerja keuangan sebuah entitas (IAI, 2018). Tujuannya adalah untuk menyajikan informasi tentang posisi keuangan, kinerja keuangan, dan arus kas entitas yang dapat digunakan oleh berbagai pihak dalam mengambil keputusan. Informasi yang terkandung dalam laporan keuangan akan memudahkan penggunanya untuk pengambilan keputusan sehingga laporan keuangan tersebut harus wajar dan berdasarkan keadaan yang sebenarnya. Untuk memastikan laporan keuangan wajar diperlukan audit eksternal supaya laporan dipastikan sesuai standar akuntansi di Indonesia. Keyakinan atas laporan keuangan sangat di- pengaruhi oleh kualitas audit (Hajering, Suun dan Muslim, 2019).

Walaupun demikian, laporan keuangan meskipun di audit oleh akuntan publik, tetap mungkin mengalami risiko salah saji. Hal tersebut dapat dibuktikan dengan kasus kegagalan audit yang terjadi pada EY-Indonesia. EY-Indonesia dikenakan denda sebesar $\$ 1$ juta oleh $P C A O B$ karena telah memberikan opini WTP (wajar tanpa pengecualian) pada PT Indosat Tbk periode 2011 yang tidak didasarkan dengan bukti memadai mengenai transaksi persewaan menara selular yang dilakukan klien $(P C A O B, 2017 \mathrm{~b})$.

Berdasarkan pada sumber Majalah ICT (Salah Audit Keuangan Indosat, 2017), PT Indosat Tbk 
telah melakukan penjualan menara kepada PT Tower Bersama Infrastructure Tbk dan anak perusahaannya yaitu PT Solusi Menara Indonesia yang disewa kembali oleh Indosat. Aktivitas penyewaan kembali diakui sebagai sewa operasi oleh PT Indosat Tbk. Namun pada saat EY-Amerika melakukan pemeriksaan atas transaksi sewa tersebut, EY-Amerika menemukan bahwa nilai present value of minimum lease payments (PVMLP) atas penyewaan menara hampir sama dengan nilai Fair Value (FV) menara yang disebut sebagai aset, sehingga dapat dikategorikan sebagai sewa pembiayaan, maka selisih lebih dalam hasil penjualan jumlah tercatat tidak dapat diakui segera sebagai penghasilan oleh penjual-lessee, namun ditangguhkan dan diamortisasi selama masa sewa (IAI, 2018). Hal ini juga berlaku untuk sewa pembiayaan umum dimana keuntungan yang didapat dari penjualan aset harus ditangguhkan dan diamortisasi selama masa sewa. Hal ini mengakibatkan pendapatan PT Indosat Tbk pada tahun 2011 mengalami Overstatement (pengakuan yang berlebih) karena telah mengakui dahulu keuntungan tersebut, yang seharusnya diamortisasikan selama masa sewa. Dampak dari permasalahan ini membuat harga saham PT Indosat Tbk menjadi turun.

Hal ini terjadi karena EY-Indonesia telah melewatkan proses audit pada tahap pengujian pengendalian dan uji subtantif atas transaksi terhadap akun sewa sehingga tidak dapat menemukan bukti kuat mengenai persewaan menara yang dilakukan klien. Ketika proses audit yang dijalankan belum tepat maka EY-Indonesia melanggar kode etik profesi yaitu prinsip kepentingan publik (profesionalisme seorang auditor) karena tidak memberikan keyakinan atas laporan audit yang dihasilkan (PCAOB, 2017a).

Menurut Arens, Elder dan Beasley (2017) proses audit terhadap laporan keuangan terdiri dari empat fase, yaitu: pertama perencanaan pendekatan audit dengan mengevaluasi latar belakang klien, menilai risiko yang mungkin terjadi dan lingkungan terkait; kedua pengujian pengendalian dan pengujian subtantif atas transaksi dengan melihat prosedur pengendalian telah ditetapkan secara konsisten dan untuk mengetahui kemungkinan salah saji dalam pencatatan; ketiga prosedur dan pengujian atas rincian saldo dengan melakukan prosedur audit yang telah ditentukan untuk menguji salah saji dalam laporan keuangan; keempat penyelesaian audit dan kewajiban menerbitkan laporan audit dengan melengkapi audit.
Prosedur harus dilakukan dan berikan opini audit kepada pihak manajemen maupun komite audit.

Seorang auditor dalam melaksanakan audit harus mematuhi seluruh standar audit (SA) dan ketentuan etika yang relevan untuk memberikan opini. Seorang auditor juga harus memiliki keyakinan yang memadai mengenai apakah keseluruhan laporan keuangan bebas dari kesalahan. Keyakinan auditor diperoleh dengan cara memperoleh bukti audit yang cukup dalam menurunkan risiko audit (SA 200). Bukti audit yang dirasa cukup dan kompeten akan digunakan oleh auditor untuk merumuskan opini yang tepat, sehingga meningkatkan kualitas audit.

Kualitas audit didefiniskan dari gabungan dimensi proses dan dimensi hasil. Pertama, dimensi proses mengukur pelaksanaan audit yang dilakukan dengan ketaatan pada standar yang ditetapkan. Kedua, dimensi hasil mengukur peningkatan keyakinan pengguna laporan keuangan atas laporan keuangan yang telah di audit (Julianto, 2016). Akuntan publik yang melaksanakan audit sesuai dengan standar akan melaksanakan audit sesuai dengan tanggung jawab profesional, mengacu pada kode etik dan sistem pengendalian mutu, memiliki kompetensi yang cukup dengan mengikuti pelatihan muthakir dari KAP, dan dapat menentukan audit adjustment yang tepat sesuai dengan diskusi tim audit, serta hasil audit yang di review oleh atasan auditor sehingga dalam melaksanakan audit dapat mendapatkan bukti audit yang dirasa cukup dan kompeten. Jika auditor melaksanakan kegiatan audit mengikuti standar maka auditor disebut mampu memberikan opini audit yang tepat sehingga dapat meyakinkan pengguna laporan keuangan sehingga dapat disimpukan memiliki kualitas audit yang tinggi. Audit yang berkualitas berguna dalam peningkatan relevansi dan keandalan informasi laporan keuangan (Lee dan Sukartha, 2017).

Faktor-faktor yang diprediksi dapat mempengaruhi kualitas audit diantaranya adalah kualitas internal auditor, yang terdiri dari profesionalisme, risiko audit dan tekanan waktu atas biaya serta biaya audit. Menurut Fietoria dan Manalu (2016) profesionalisme auditor adalah sikap yang bertanggung jawab pada apa yang telah ditugaskan dengan tekun dan seksama. Auditor dengan profesionalisme tinggi, mempunyai keteguhan yang tinggi pada profesinya dengan menyadari pentingnya hasil pekerjaan yang dilakukan untuk masyarakat, sehingga auditor akan 
melaksanakan audit sesuai tanggung jawab professional, mengacu pada kode etik dan sistem pengendalian mutu untuk memberikan opini yang tepat dari bukti audit yang cukup yang telah didiskusikan bersama tim audit dan di review oleh atasan. Ketepatan opini yang diberikan maka akan meningkatkan keyakinan pengguna laporan keuangan, sehingga dapat disimpulkan kualitas audit tinggi. Hal serupa dinyatakan oleh Pramesti dan Wiratmaja (2017), dimana profesionalisme berpengaruh signifikan dan berkorelasi positif terhadap kualitas audit. Hasil penelitian ini juga sejalan dengan Safaroh, Susilawati dan Halim (2016). Hasil temuan Suardinatha dan Wirakusuma (2016) berbeda di mana menunjukkan profesionalisme tidak berpengaruh terhadap kualitas audit.

Kualitas internal auditor yang kedua adalah risiko audit. Menurut Guy, Alderman dan Winters (2001) dalam Suryo (2017) risiko audit merupakan tingkat ketidakpastian yang dirasakan auditor saat melaksanakan tugas audit yang menyebabkan tidak mencapai sasaran, sehingga akan ada risiko kesalahan dalam memberikan opini. Sun dan Liu (2011) menyatakan bahwa efektifitas auditor yang tergabung dalam KAP Big Four menjadi lebih tinggi jika menghadapi klien yang memiliki resiko litigasi tinggi. Seringkali pengukuran ini menjadi penentu kualitas auditor yang nantinya dapat digunakan untuk mengukur kualitas audit (Hinarno dan Osesoga, 2016). Klien dengan risiko litigasi tinggi dapat mengidentifikasi tingginya risiko audit. Risiko audit yang rendah ditandai dengan auditor mampu dalam mengukur kompleksitas transaksi usaha klien, auditor mampu mempelajari laporan audit, mampu memahami keefektifan internal kontrol, mampu menilai kondisi organisasi klien, dan mampu membuat perencanaan audit yang sesuai, sehingga dalam melaksanakan tugas audit mendorong auditor untuk menerapkan teknikteknik audit yang tepat serta sesuai dengan kode etik, standar profesional, dan pengendalian mutu, serta selalu mendiskusikan terkait adanya adjustment yang terjadi dengan tim audit dan hasil audit yang di review oleh atasan dalam memperoleh bukti audit yang dirasa cukup dan dapat dipertanggungjawabkan. Lengkapnya bukti audit sebagai penunjang pemberian opini dapat meyakinkan pengguna laporan keuangan, sehingga menandakan kualitas audit yang tinggi. Kesimpulan ini didukung oleh Pratama dan Merkusiwati (2014), Suryo (2017) serta Julianto, Yadnyana dan Suputra (2016) yang menyatakan bahwa risiko audit berpengaruh terhadap kualitas audit.

Kualitas internal auditor yang ketiga adalah tekanan anggaran waktu yang diprediksi dapat mempengaruhi kualitas audit adalah. Tekanan anggaran waktu adalah tekanan kepada auditor terkait anggaran dan waktu yang terbatas untuk menyelesaikan suatu pekerjaan (Zam dan Rahayu, 2015). Tekanan anggaran waktu yang rendah ditandakan dengan kecukupan waktu yang diterima auditor untuk melaksanakan tugas audit, sehingga auditor bisa memilih dan menerapkan prosedur audit secara keseluruhan yang dibutuhkannya sesuai dengan kode etik, prosedur profesional, dan sistem pengendalian mutu. Auditor akan mendapatkan bukti audit yang lengkap dan kompeten sehingga auditor dapat memberikan pendapat. Kelengkapan bukti audit dapat meningkatkan keyakinan pengguna laporan keuangan, yang artinya kualitas audit tinggi. Sejalan dengan penelitian Pratama dan Merkusiwati (2014) dan Suryo (2017) yang menyimpulkan bahwa tekanan anggaran waktu berpengaruh terhadap kualitas audit. Bertolak belakang dengan Zam dan Rahayu (2015) serta Oklivia dan Marlinah (2014) yang memperoleh hasil penelitian bahwa tekanan anggaran waktu tidak berpengaruh terhadap kualitas audit.

Selanjutnya, audit fee juga diprediksi dapat mempengaruhi kualitas audit. Pramesti dan Wiratmaja (2017) menyebutkan bahwa besarnya biaya audit yang diterima oleh KAP atas pelaksanaan jasa audit ditentukan berdasarkan risiko penugasan, kompleksitas dari jasa, tingkat keahlian yang dibutuhkan dan struktur biaya KAP tersebut. Pengukuran besaran audit yang sama juga digunakan oleh Kuntari, Chariri dan Nurdhiana (2017) dengan penambahan pengukuran usaha KAP untuk mempertahankan kliennya. Chung dan Wynn (2014) menemukan bahwa KAP akan membebankan biaya audit yang lebih tinggi pada perusahaan yang memiliki resiko tata kelola yang tinggi pula. Audit Fee akan semakin tinggi apabila struktur biaya KAP tinggi atau baik, yang ditandai dengan adanya batasan besaran fee audit sesuai kebutuhan dari KAP, sehingga KAP memiliki kecukupan dana untuk memberikan auditor training, promosi, dan gaji yang memadai. Auditor yang diberikan training, promosi dari $\mathrm{KAP}$, dan memiliki struktur gaji yang memadai dapat meningkatkan integritas, independensi, dan kerja keras dalam melaksanakan tugas, sehingga auditor akan memilih prosedur audit dan melaksanakan teknik audit dengan tepat dan benar serta sesuai dengan kode etik dan sistem pengendalian mutu. Ketepatan auditor melaksanakan teknik audit mendorong auditor menemukan bukti audit yang kompeten untuk 
mendasari pemberian opini yang tepat atas laporan keuangan klien, sehingga dapat meningkatkan keyakinan pengguna laporan keuangan yang pada akhirnya meningkatkan kualitas aduit. Penelitian Harish, Rahayu dan Aminah. (2014), Zam dan Rahayu (2015) serta Pramaswaradana dan Astika (2017) yang menyatakan biaya audit berpengaruh pada kualitas audit. Namun tidak sejalan dengan hasil penelitian Dhimadhanu (2016) yang menyatakan bahwa audit fee tidak berpengaruh terhadap kualitas audit.

Penelitian yang dilakukan sebelumnya memberikan hasil yang berbeda-beda terutama pada sampel yang berbeda kota. Penelitian ini ingin menguji kembali pengaruh kualitas internal auditor, yaitu profesionalisme, risiko audit dan tekanan anggaran waktu serta biaya audit terhadap kualitas audit. Penelitian ini juga membatasi responden hanya pada auditor yang menjabat sebagai senior dan jabatan diatasnya karena dinilai ikut serta aktif dalam penentuan opini yang merupakan rumusan dari kualitas audit, sedangkan pada penelitian lainnya, pembatasan responden ini jarang digunakan. Tujuan penelitian ini untuk memperoleh bukti empiris mengenai pengaruh kualitas internbal auditor yang terdiri dari profesionalisme, risiko audit dan tekanan anggaran waktu serta biaya audit terhadap kualitas audit yang dihasilkan.

\section{KAJIAN LITERATUR DAN PENGEMBANGAN HIPOTESIS}

Kajian Literatur

Audit

Arens dkk. (2017) menyatakan bahwa audit adalah proses pengumpulan dan menilai bukti tentang informasi yang digunakan untuk menentukan dan melaporkan kesesuaian antara informasi dengan kriteria.

Menurut Suryo (2017) kualitas audit adalah kemungkinan seorang auditor dalam menemukan dan melaporkan penyelewengan dalam sistem akuntansi klien. Pengukuran oleh Julianto dkk. (2016) mengukur kulitas audit melalui proses dan hasil dari audit. Hapsoro dan Santoso (2018) menyatakan bahwa perikatan audit pada klien yang sama dalam beberapa periode berturut-turut dapat meningkatkan pemahaman auditor akan kinerja klien yang berdampak pada pemahaman mendalam atas klien sehingga meningkatkan kualitas audit. Hal ini dapat mendorong spesialiasi audit yang juga dapat menjadi salah satu pengukuran kualitas audit (Kartika dan Nahumury, 2014). Audit yang berkualitas memiliki peren penting dalam penghindaran perusahaan dari kasus litigasi (Skinner dan Srinivasan, 2012).

Schoeder (1986) dalam Suryo (2017) menyimpulkan bahwa ada lima faktor penting penentu kualitas audit yaitu (1) Perhatian partner dan manajer KAP dalam proses audit; (2) Perencanaan dan pelaksanaan; (3) Komunikasi yang baik antara tim audit dengan manajemen klien; (4) Independensi anggota tim; dan (5) Kemutakhiran audit. Menurut Greg dan Graham (2013) dalam Pramesti dan Wiratmaja (2017) ada dua pendekatan untuk mengevaluasi sebuah keputusan, yaitu berorientasi hasil yang akan mengukur kualitas audit melalui hasil audit tersebut dan berorientasi proses (process oriented) yang akan mengukur kualitas keputusan dengan tingkat kepatuhan auditor terhadap standar audit serta spesialisasi auditor. Knechel dkk. (2013) melengkapi indikator pengukuran kualitas yang meliputi input, proses dan output.

Penelitian Deis dan Giroux (1992) dalam Deli, Fatma dan Syarif (2015) menyatakan terdapat empat hal yang disaumsikan memiliki korelasi dengan kualitas audit, yaitu: (1) Waktu auditor dalam melakukan pemeriksaan pada klien; (2) Jumlah klien; (3) Kesehatan keuangan klien; dan (4) Review oleh pihak ketiga.

\section{Profesionalisme}

Menurut Fietoria dan Manalu (2016) profesionalisme adalah sikap bertanggungjawab pada tugas yang diberikan kepadanya dengan tekun dan seksama. Menurut Idawati (2018), profesionalisme adalah konsep pengukuran pandangan profesional terhadap profesi mereka yang tergambar pada perilakunya sebagai auditor. Menurut Institut Akuntan Publik Indonesia (2018), setiap akuntan publik terutama yang bersertifikasi, harus dapat mematuhi prinsip dasar etika profesi akuntan publik, yaitu integritas, objektif, berkompetensi profesional dengan sikap cermat dan hati-hati, dapat menjunjung kerahasiaan, dan berperilaku profesional.

Futri dan Juliarsa (2014) menyebutkan bahwa profesionalisme adalah sebuah tanggung jawab setiap individu untuk berperilaku lebih baik dari hanya sekedar mematuhi undang-undang, kode etik, dan peraturan. Semiu dan Temitope (2010) dalam Pramesti dan Wiratmaja (2017) menyebutkan bahwa ada lima indikator yang mengacu sifat profesional seorang auditor, yaitu: (1) Dedikasi; (2) 
Kewajiban sosial; (3) Mandiri; dan (4) Keyakinan terhadap peraturan profesi serta hubungan dengan sesama profesi. Penelitian yang dilakukan oleh Idawati (2018) pada auditor dari KAP di DKI Jakarta, menyatakan profesionalisme memiliki pengaruh terhadap kualitas audit. Hipotesi pertama adalah: $\mathrm{Ha}_{1}$ : Profesionalisme berpengaruh terhadap kualitas audit

\section{Risiko Audit}

Menurut Guy, Alderman dan Winters (2001) dalam Suryo (2017) risiko audit adalah tingkat ketidakpastian yang dihadapi auditor saat melaksanakan tugas audit yang menyebabkan tidak mencapai sasaran, sehingga akan ada risiko kesalahan dalam memberikan opini. Menurut Pratama dan Merkusiwati (2014) risiko audit merupakan risiko adanya kesalahan dari auditor untuk memberi opini WTP atas laporan keuangan yang memiliki salah saji secara material. Peningkatan risiko audit berhubungan dengan peningkatan kompleksitas penugasan. Semakin kompleks suatu penugasan audit, maka semakin besar kemungkinan salah saji yang dilakukan klien. Mindak dan Heltzer (2011) menemukan bahwa kasus lingkungan yang berhubungan dengan keberlangsungan usaha perusahaan mempengaruhi penilaian audit risk.

Menurut Whittington dan Pany (2016), risiko audit adalah risiko bahwa auditor dengan tidak sadar salah memodifikasi hasil pendapat mereka atas laporan keuangan yang salah saji secara material. Ada 3 kategori model dalam risiko audit, yaitu: (1) Risiko bawaan karena terjadi salah saji material dalam sebuah akun, dengan asumsi tidak ada kontrol; (2) Risiko pengendalian karena terjadi salah saji material dalam sebuah pernyataan dan tidak terdeteksi secara tepat waktu oleh pihak pengendalian internal; dan (3) Risiko deteksi karena auditor tidak mampu mendeteksi salah saji material yang ada dalam satu asersi. Penelitian Ariningsih dan Mertha (2017) menyatakan terdapat pengaruh negatif antara risiko audit dengan kualitas audit.

$\mathrm{Ha}_{2}$ : Risiko Audit berpengaruh terhadap kualitas audit.

\section{Tekanan Anggaran Waktu}

Adanya keterbatasan dalam menyelesaikan suatu pekerjaan. Inilah yang dimaksud dengan tekanan anggaran waktu. Tekanan anggaran waktu yang ketat dapat membuat auditor lalai dan kurang teliti dalam melaksanakan bagian dari program audit yang penting sehingga menyebabkan kuali- tas audit mengalami penurunan (Zam dan Rahayu, 2015). Dwimilten dan Riduwan (2015) menyebutkan bahwa tekanan waktu memiliki dua jenis, yaitu: (1) Time budget pressure adalah saat auditor diwajibkan melakukan efisiensi terhadap anggaran waktu yang telah ditetapkan; dan (2) Time deadline pressure adalah saat auditor dituntut untuk menyelesaikan tugas audit tepat waktu.

Menurut Muhsyi (2013) dalam Safaroh dkk. (2016), indikator variabel tekanan anggaran waktu terdiri atas waktu yang terbatas dalam melakukan tugas, auditor mampu menyelesaikan tugas pada waktu yang telah ditentukan, target waktu dalam tugas terpenuhi, kelonggaran waktu apabila dibutuhkan, fokus dengan tugas meskipun waktu terbatas, terjadi komunikasi terkait dengan anggaran waktu, dapat melakukan efisiensi proses audit, atasan menilai kinerja, anggaran waktu yang tidak fleksibel serta anggaran waktu adalah keputusan mutlak atasan. Sedangkan menurut $\mathrm{Hu}-$ tabarat (2012) dalam Zam dan Rahayu (2015) menyebutkan ada dua indikator tekanan anggaran waktu, yaitu keketatan anggaran waktu dan ketercapaian anggaran waktu.

Penelitian Gundry dan Liyanarachchi (2007) serta Gaol (2018) menemukan bahwa ada hubungan signifikan antara tekanan anggaran watu dengan penurunan kualitas audit. Auditor yang memiliki waktu sempit dapat melakukan tindakan pengurangan prosedur audit dan penerimaan informasi tidak memadai dari klien. Hal ini menyebabkan penurunan kualitas audit. Svanberg dan Ohman (2013) menemukan hasil yang berbeda di mana tekanan waktu memiliki pengaruh tidak langsung pada penurunan kualitas audit.

$\mathrm{Ha}_{3}$ : Tekanan Anggaran Waktu berpengaruh terhadap kualitas audit.

\section{Biaya Audit}

Mulyadi (2002) dalam Pramesti dan Wiratmaja (2017) menyatakan bahwa biaya audit merupakan pendapatan akuntan publik setelah melaksanakan tugasnya. Besaran biaya audit biasanya ditentukan dari kompleksitas jasa audit yang diberikan, resiko penugasan, tingkat keahlian dan struktur dalam pembiayaan KAP. Biaya audit umumnya dalam bentuk uang atau bentuk barang ataupun bentuk lainnya yang diterima dari klien atau pihak lain untuk memperoleh perikatan dari klien atau pihak lain (Zam dan Rahayu, 2015). Menurut Agoes (2012) dalam Zam dan Rahayu (2015) indikator dari biaya audit biasanya diukur dari: (1) Risiko penugasan; (2) Kompleksitas jasa audit yang diberikan; (3) Struktur Biaya KAP serta pertimbangan profe- 
sional lain; dan (4) Ukuran KAP.

Penelitian Prabhawanti dan Widhiyani (2018) pada auditor di KAP yang berlokasi di Bali menemukan besarnya biaya audit berpengaruh positif terhadap kualitas audit. Kuntari dkk. (2017) dengan objek penelitian auditor di Semarang juga menyatakan hal serupa. Rahmina dan Agoes (2014) juga menyatakan hubungan positif antara audit fee dengan kualitas audit. Namun Yandari dan Sudaryati (2017) menyatakan bahwa semakin besar audit fee semakin besar pula tekanan kepada auditor agar dapat mengeluarkan opini yang sesuai dengan dorongan klien sehingga mengancam penurunan kualitas audit.

$\mathrm{Ha}_{4}$ : Audit Fee berpengaruh terhadap kualitas audit.

Model Penelitian

Model penelitian yang digunakan sebagai berikut:

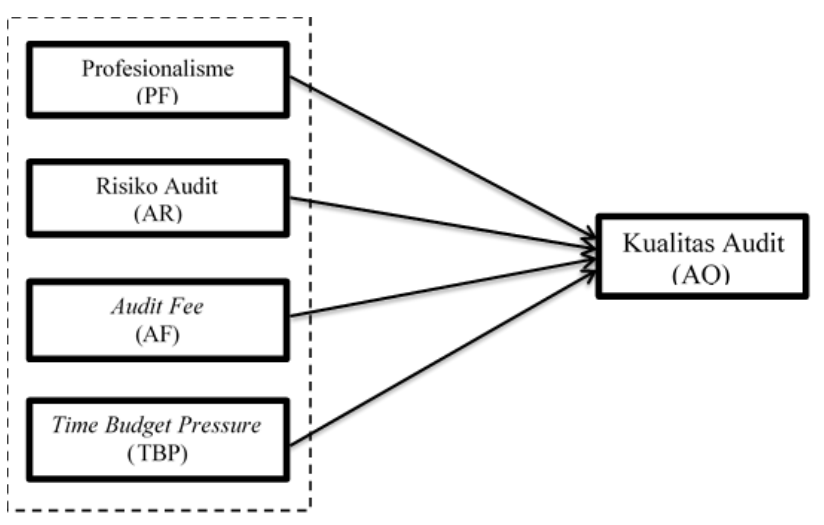

Gambar 1. Model Penelitian

\section{METODE PENELITIAN}

Metode penelitian ini menggunakan penelitian hubungan sebab akibat (causal study). Peneliti memilih metode causal study karena bertujuan untuk menguji dan mendapatkan bukti empiris mengenai pengaruh profesionalisme, risiko audit, tekanan anggaran waktu dan biaya audit terhadap kualitas audit. Jenis data yang digunakan adalah data primer yang diperoleh dengan melakukan teknik pengumpulan data melalui penyebaran kuesioner pada kantor akuntan publik (KAP) di Tangerang dan Jakarta. Pengambilan sampel menggunakan metode nonprobability sampling dan dengan menggunakan teknik convenience sampling. Teknik analisis data menggunakan analisis regresi linear berganda. Analisis data menggunakan SPSS 25. Persamaan regresi linear berganda dapat dituliskan sebagai berikut:

$$
\mathrm{AQ}=\mathrm{A}+\mathrm{B} 1 \mathrm{PF}+\mathrm{B} 2 \mathrm{AR}+\mathrm{B} 3 \mathrm{TBP}+\mathrm{B} 4 \mathrm{AF}+\mathrm{E}
$$

Keterangan:

$\begin{array}{ll}\text { AQ } & =\text { Kualitas Audit } \\ \text { A } & =\text { Konstanta Regresi } \\ \text { B1 , B2, B3, B4 }= & \text { Koefisiensi Regresi } \\ \text { PF } & =\text { Profesionalisme } \\ \text { AR } & =\text { Risiko Audit } \\ \text { TBP } & =\text { Time Budget Pressure } \\ \text { AF } & =\text { Audit Fee } \\ \text { E } & =\text { Kesalahan Prediksi (error of es- } \\ & \text { timation) }\end{array}$

Populasi dan sampel penelitian

Objek penelitian ini adalah KAP di Tangerang dan Kota Jakarta. Responden harus memenuhi kriteria, yaitu auditor telah memiliki masa kerja paling sedikit 1 tahun, posisi minimal senior auditor, dan sudah pernah melaksanakan seluruh tahapan audit yang ada. Tahapan audit yang dimaksud meliputi tahap perencanaan pendekatan audit, pengujian subtantif dan pengendalian, prosedur analitis serta pengujian saldo, dan penyelesaian audit dan akhirnya dapat memberikan laporan audit.

\section{Variabel Penelitian}

Kualitas audit digunakan sebagai variabel dependen. Kualitas audit adalah proses pelaksanaan audit yang dilakukan oleh auditor secara taat pada standar audit, yang sesuai dengan kode etik dan sistem pengendalian mutu, dilaksanakan oleh auditor yang memiliki kompetensi tinggi, dan menerapkan teknik-teknik audit yang tepat untuk mendorong auditor mendapatkan bukti yang cukup dan kompeten serta hasil audit yang di review oleh atas yang bertujuan untuk meningkatkan keyakinan pengguna laporan keuangan dari laporan audit tersebut. Variabel ini diukur dengan skala likert 1-5 dengan 9 pernyataan positif.

Variabel independen pertama yang digunakan adalah profesionalisme yang berdefinisi sikap tanggung jawab auditor atas pekerjaannya yang teguh pada profesi dan menyadari hasil pekerjaannya sangat penting untuk masyarakat agar dalam melaksanakan audit akan sesuai dengan prosedur audit serta akan mengacu pada kode etik, standar profesional, dan sistem pengendalian mutu, sehingga akan meningkatkan kualitas audit. Variabel ini diukur dengan skala likert 1-5 dengan 4 pernyataan positif.

Variabel independen kedua adalah risiko audit 
yang berdefinisi tingkat ketidakpastian yang dialami auditor dalam pelaksanaan tugas auditnya yang mendorong auditor untuk mengukur kompleksitas transaksi usaha klien, mampu menilai laporan audit terdahulu, dan mampu menilai keefektifan internal kontrol klien, sehingga dalam melaksanakan tugasnya harus dilakukan oleh auditor yang memiliki kompetensi tinggi untuk menerapkan teknik-teknik audit yang tepat untuk mendapat bukti audit yang cukup dan kompeten untuk merumuskan opini, dan dapat menghasilkan kualitas audit yang tinggi. Variabel ini diukur dengan skala likert 1-5 dengan 1 pernyataan positif dan 9 pernyataan negatif.

Variabel independen ketiga yaitu lama waktu pengerjaan adalah anggaran waktu yang sempit terhadap auditor untuk menyelesaikan tugas audit sesuai target. Apabila klien memberikan batasan waktu dalam tugas audit dengan tepat dan cukup akan mendorong auditor untuk menerapkan seluruh prosedur audit yang dibutuhkan agar mendapatkan bukti yang cukup dan kompeten, sehingga kualitas audit yang dihasilkan menjadi tinggi. Variabel ini diukur dengan skala likert 1-5 dengan 7 pernyataan positif dan 1 pernyataan negatif.

Variabel independen keempat adalah biaya audit yang berdefinisi besaran fee yang diterima auditor berdasarkan pada risiko penugasan, kompleksitas jasa audit, tingkat keahlian yang diperlukan agar dalam melaksanakan audit dapat ditangani oleh auditor yang memiliki keahlian tinggi. Hal ini membantu auditor untuk mendapatkan bukti audit yang kompeten dan hasil audit selalu di review oleh atasan, sehingga kualitas audit akan tinggi. Variabel ini diukur dengan skala likert 1-5 dengan 11 pernyataan positif.

\section{HASIL DAN PEMBAHASAN}

Pengambilan data menggunakan kuesioner didistribusikan ke 23 KAP. Sebanyak 201 kuesioner yang disebar, telah kembali sebanyak 179 kuesioner. Namun terdapat 78 kuesioner yang tidak dapat terpakai sehingga hanya sebanyak 101 kuesioner yang digunakan dalam pengolahan data. Berikut data pendistribusian kuesioner yang dilakukan:
Tabel 1. Distribusi Kuesioner di KAP Jakarta dan Tangerang

\begin{tabular}{|c|c|c|c|}
\hline No. & Nama KAP & Dikirim & Terpakai \\
\hline 1 & Crowe Indonesia & 5 & 3 \\
\hline 2 & $\begin{array}{l}\text { M. Yasin, Toni, Ratim, } \\
\text { Sumijono }\end{array}$ & 8 & 4 \\
\hline 3 & Ispiady \& Dande & 5 & 5 \\
\hline 4 & Andi, Arifin, dan Rekan & 10 & 6 \\
\hline 5 & Armanda \& Enita & 20 & 8 \\
\hline 6 & $\begin{array}{l}\text { Joachim Sulistyo \& } \\
\text { Rekan }\end{array}$ & 3 & 3 \\
\hline 7 & Susianto Arona & 5 & 2 \\
\hline 8 & $\begin{array}{ll}\text { Kanaka } & \text { Puradiredja } \\
\text { Suhartono } & \\
\end{array}$ & 20 & 8 \\
\hline 9 & Ruslim \& Ruslim & 3 & 3 \\
\hline 10 & Tribowo Yulianti & 5 & 2 \\
\hline 11 & $\begin{array}{l}\text { Husni, Mucharam, \& } \\
\text { Rasidi }\end{array}$ & 10 & 6 \\
\hline 12 & $\begin{array}{l}\text { Tasnim Ali Widjanarko } \\
\text { \& Rekan }\end{array}$ & 6 & 4 \\
\hline 13 & $\begin{array}{l}\text { Krisnawan, Busroni, } \\
\text { Achsin }\end{array}$ & 10 & 8 \\
\hline 14 & $\begin{array}{l}\text { Suganda Akna Suhri \& } \\
\text { Rekan }\end{array}$ & 10 & 6 \\
\hline 15 & Rama Wendra & 15 & 9 \\
\hline 16 & BDO Indonesia & 20 & 10 \\
\hline 17 & Justinus A. Shidarta & 6 & 5 \\
\hline 18 & Susianto Arona Jakarta & 8 & 6 \\
\hline 19 & Drs. Sutopo Insja & 5 & 3 \\
\hline 20 & Purbalaud \& Rekan & 12 & 0 \\
\hline 21 & $\begin{array}{l}\text { Soejatna, Mulyana, dan } \\
\text { Rekan }\end{array}$ & 7 & 0 \\
\hline 22 & Johannes Juara \& Rekan & 5 & 0 \\
\hline 23 & Leonard Pangaribuan & 3 & 0 \\
\hline \multicolumn{2}{|c|}{ TOTAL } & 201 & 101 \\
\hline
\end{tabular}

Sumber: Data diolah

\section{Uji Statistik Deskriptif}

Statistik deskriptif menyajikan deskipsi suatu data sehingga dapat memberikan gambaran secara konseptual yang lebih jelas dan lebih mudah dimengerti pembaca (Ghozali, 2018). Hasil statistik deskriptif data penelitian ini disajikan dalam tabel 2.

Tabel 2. Hasil Uji Statistik Deskriptif

\begin{tabular}{|l|l|l|l|l|}
\hline No & Variabel & Mean & Min & Max \\
\hline 1 & Kualitas audit & 37.22 & 30 & 45 \\
\hline 2 & Profesionalisme & 15.80 & 4 & 20 \\
\hline 3 & Risiko Audit & 26.39 & 13 & 38 \\
\hline 4 & Tekanan anggaran waktu & 30.07 & 18 & 40 \\
\hline 5 & Audit Fee & 39.92 & 25 & 50 \\
\hline
\end{tabular}

Sumber: Data diolah

Berdasarkan nilai mean untuk variabel kualitas audit sebesar 37.22 yang terdiri dari 9 pern- 
yataan, maka dapat disimpulkan bahwa rata-rata responden menjawab pada skor 4,14 atau berada pada skor Setuju (S) untuk variable kualitas audit. Angka ini menginformasikan bahwa responden memberikan audit yang berkualitas pada profesinya sebagai seorang auditor yang didukung dengan proses audit sesuai dengan prosedur dan pekerjaan yang akan selalu di review oleh atasan.

Untuk variabel profesionalisme, nilai mean sebesar 15.80 dengan 4 pernyataan sehingga dapat disimpulkan rata-rata responden menjawab pada skor 3,95 atau berada pada skor Netral (N). Angka ini menginformasikan bahwa responden rata-rata memiliki Profesionalisme yang cukup dalam melaksanakan audit dengan memiliki kesadaran akan pentingnya auditor untuk masyarakat dan bertanggung jawab atas pekerjaannya.

Untuk variabel risiko audit, nilai mean sebesar 26.39 dengan 10 pernyataan sehingga dapat disimpulkan rata-rata responden menjawab pada skor skor 2,639 atau berada pada skor Setuju (S). Angka ini menginformasikan bahwa sebagian besar responden beranggapan Risiko Audit yang dihadapi rendah karena auditor mampu mengukur tingkat kompleksitas jasa yang diberikan, yang membuat auditor dengan mudah mempelajari struktur organisasi klien dan mampu menilai laporan audit terdahulu, sehingga auditor akan memilih teknikteknik audit yang tepat.

Untuk variabel audit fee, nilai mean sebesar 39.92 dengan 11 pernyataan sehingga dapat disimpulkan rata-rata responden menjawab pada skor 3,63 atau berada pada skor Netral (N). Angka ini menginformasikan bahwa responden memiliki rata-rata Audit Fee yang cukup untuk melaksanakan audit yang didukung dengan struktur biaya KAP baik, memiliki kemampuan yang ahli dan pengalaman yang cukup sehingga membuat auditor memilih prosedur yang tepat dan di review oleh atasan.

Untuk variabel tekanan anggaran waktu, nilai mean sebesar 30.07 dengan 8 pernyataan sehingga dapat disimpulkan rata-rata responden menjawab pada skor 3,76 atau berada pada skor Netral (N). Angka ini menginformasikan bahwa rata-rata responden memiliki tekanan anggaran waktu yang cukup dalam melaksanakan audit, sehingga auditor fokus dalam melaksanakan tugasnya yang membuat auditor mampu untuk memenuhi target yang telah ditetapkan.

\section{Uji Reliabilitas}

Keandalan kuesioner ditunjukkan dengan jawaban responden yang konsisten dan stabil. Uji reliabilitas dalam penelitian ini menggunakan uji koefisien Cronbach alfa dengan hasil yang disajikan pada tabel 3 .

Tabel 3. Hasil Uji Reliabilitas

\begin{tabular}{|l|l|}
\hline Variabel & $\begin{array}{l}\text { Cronbach's Alpha (a) } \\
\text { Based on Standard- } \\
\text { ized Items }\end{array}$ \\
\hline Kualitas Auditor (AQ) & 0,794 \\
\hline Profesionalisme (PF) & 0,747 \\
\hline Risiko Audit (AR) & 0,844 \\
\hline $\begin{array}{l}\text { Tekanan Anggaran } \\
\text { Waktu (TBP) }\end{array}$ & 0,776 \\
\hline Biaya Audit (AF) & 0,809 \\
\hline
\end{tabular}

Sumber: Data diolah

Hasil uji Cronbach's Alpha (a) untuk variabel dependen dan independent dapat dilihat dari tabel 3. Seluruh variabel yang diuji memiliki Cronbach's Alpha $(\alpha)>0,7$, sehingga dapat dikatakan reliabel.

\section{Uji Validitas}

Menurut Gozhali (2018), uji validitas digunakan untuk mengukur tingkat validitas kuesioner yang digunakan. Jika kuesioner dapat mengungkapkan sesuatu yang diukur oleh kuesioner, maka dinyatakan bahwa kuesioner tersebut valid. Uji validitas dilakukan dengan menggunakan alat uji Pearson Correlation dengan hasil sebagai berikut:

Tabel 4. Hasil Uji Validitas

\begin{tabular}{|l|l|}
\hline Variabel & Sig. (2-tailed) \\
\hline Kualitas Auditor (AQ) & 0,000 \\
\hline Profesionalisme (PF) & 0,000 \\
\hline Risiko Audit (AR) & $0,000-0,001$ \\
\hline $\begin{array}{l}\text { Time Budget Pressure } \\
\text { (TBP) }\end{array}$ & 0,000 \\
\hline Audit Fee (AF) & 0,000 \\
\hline
\end{tabular}

Sumber: Data diolah

Tabel 4 menunjukkan bahwa variabel Kualitas Audit yang diukur 9 pernyataan, Profesionalisme yang diukur 4 pernyataan, Risiko Audit yang diukur 11 pernyataan, tekanan anggaran waktu yang terdiri dari 8 pernyataan serta biaya audit yang terdiri dari 10 pernyataan memiliki nilai signifikansi 0,000. Dan untuk variabel risiko audit memiliki nilai signifikansi 0,000 - 0,001 atau lebih kecil dari 0,005. Hasil uji validitas menunjukkan 
semua pernyataan pada variabel dependen dan independent adalah valid.

\section{Uji Normalitas}

Uji normalitas bertujuan untuk menguji apakah variabel residual memiliki distribusi normal dalam model regresi yang telah dibentuk. Uji normalitas menggunakan metode One-Sample Kolmogorov-Smirnov (K-S). Hasil uji normalitas disajikan dalam tabel 5.

Tabel 5. Hasil Uji Normalitas

\begin{tabular}{|c|c|c|}
\hline & & $\begin{array}{l}\text { Unstandard- } \\
\text { ized Residual }\end{array}$ \\
\hline \multicolumn{2}{|l|}{$\mathrm{N}$} & 101 \\
\hline \multirow{2}{*}{$\begin{array}{l}\text { Normal Pa- } \\
\text { rameters }^{a, b}\end{array}$} & Mean & .0000000 \\
\hline & Std. Deviation & 3.02585583 \\
\hline \multirow{3}{*}{$\begin{array}{l}\text { Most Ex- } \\
\text { treme Differ- } \\
\text { ences }\end{array}$} & Absolute & .082 \\
\hline & Positive & .082 \\
\hline & Negative & -.067 \\
\hline \multicolumn{2}{|l|}{ Test Statistic } & .082 \\
\hline \multicolumn{2}{|c|}{ Asymp. Sig. (2-tailed) } & $.095^{c}$ \\
\hline
\end{tabular}

Sumber: Data diolah

Berdasarkan tabel 5, nilai signifikansi data adalah 0,095 yang berarti nilai signifikansi tersebut lebih kecil dari 0,05 sehingga dapat disimpulkan bahwa model regresi terdistribusi normal.

\section{Uji Multikolonieritas}

Uji Multikolonieritas merupakan pengujian korelasi antar variabel bebas (independen) dalam suatu penelitian. Variabel independen dalam penelitian diharapkan tidak memiliki korelasi dengan sesamanya. Pengujian multikolonieritas menggunakan Tolerance dan Variance Inflation Factor (VIF). Tabel 6 menyajikan hasil uji multikolonieritas.

Tabel 6. Hasil Uji Multikolonieritas

\begin{tabular}{|l|l|l|}
\hline \multirow{2}{*}{ Model } & \multicolumn{2}{|l|}{ Collinearity Statistics } \\
\cline { 2 - 3 } & Tolerance & VIF \\
\hline Constant & & \\
\hline PF & 0,849 & 1,178 \\
\hline AR & 0,784 & 1,275 \\
\hline TBP & 0,646 & 1,548 \\
\hline AF & 0,695 & 1,438 \\
\hline
\end{tabular}

Sumber: Data diolah

Hasil perhitungan tolerance pada tabel 6 menunjukkan bahwa seluruh variabel independen tidak memiliki nilai tolerance $<0,10$ dan tidak terdapat variabel independen yang memiliki nilai VIF
$>$ 10. Hasil ini menunjukkan bahwa tidak terdapat multikolonieritas di antara variabel independen (variabel bebas).

\section{Uji Heteroskedastisitas}

Pengujian keterjadian atas ketidaksamaan varian dari residual satu pengamatan ke pengamatan yang lain. Model regresi yang baik adalah model yang homoskedastisitas (Gozhali, 2018). Uji heteroskedastisitas dilakukan dengan menggunakan alat uji grafik Scatterplot. Hasil uji hetereskedastisitas disajikan dalam gambar 2 .

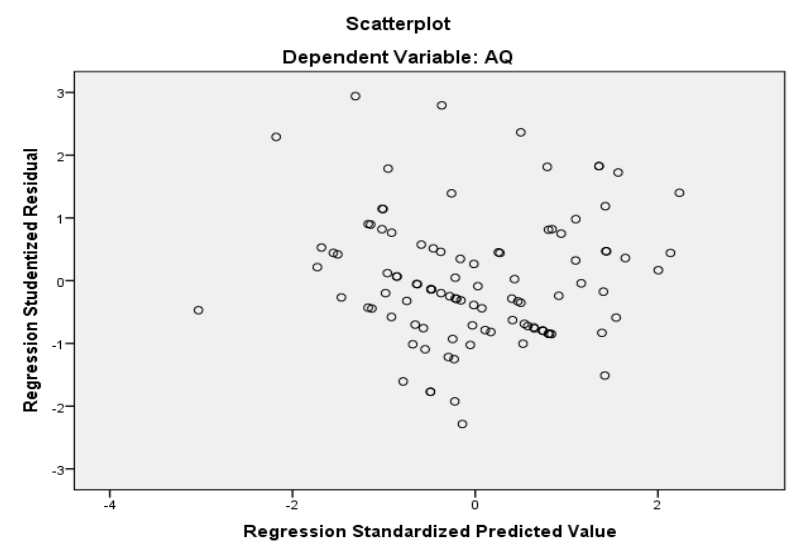

\section{Gambar 2. Grafik Scatterplot Hasil Uji Heteroskedastisitas}

Berdasarkan gambar grafik Scatterplot tersebut terlihat bahwa titik menyebar secara acak, baik di atas maupun di bawah angka 0 pada sumbu $Y$, sehingga dapat disimpulkan bahwa pada model regresi dalam penelitian ini tidak terjadi heteroskedastisitas.

\section{Uji Koefisien Determinasi}

Digunakan untuk mengukur kemampuan model untuk menjelaskan variansi variabel dependen. Tabel 7 menyajikan hasil uji koefisien determinasi.

Tabel 7. Hasil Uji Koefisien Determinasi

\begin{tabular}{|c|c|c|c|c|}
\hline \multicolumn{5}{|c|}{ Model Summary $^{\mathbf{b}}$} \\
\hline $\begin{array}{r}\text { Mol } \\
\text { del }\end{array}$ & $\mathrm{R}$ & $\begin{array}{r}\mathrm{R} \\
\text { Squa } \\
\text { re }\end{array}$ & $\begin{array}{r}\text { Adjusted } \\
\text { R Square }\end{array}$ & $\begin{array}{c}\text { Std. Error } \\
\text { of the Es- } \\
\text { timate }\end{array}$ \\
\hline 1 & $\begin{array}{r}.478 \\
\text { a }\end{array}$ & .229 & .197 & 3.088 \\
\hline
\end{tabular}

Sumber: Data diolah

Tabel 7 menunjukkan hasil nilai Adjusted $R$ Square sebesar 0,197. Pemahaman atas nilai tersebut adalah 19,7\% variabel kualitas audit dapat dijelaskan oleh keempat variabel independen yaitu Profesionalisme, Risiko Audit, tekanan waktu anggaran 
dan biaya audit. Di luar 19,7\%, yatu sebesar 80,3\% (100\%-19,7\%) dijelaskan oleh variabel lain yang tidak diteliti dalam penelitian ini. Nilai $R$ pada tabel 7 juga menunjukkan korelasi variabel independen dengan variable dependen. Nilai $R$ adalah 0.478 berada pada interval koefisien 0,40 - 0,599, sehingga dapat dijelaskan bahwa antar variabel memiliki korelasi.

\section{Uji Signifikansi Simultan} tabel 8

Hasil uji signifikansi simultan disajikan dalam

Tabel 8. Hasil Uji Simultan F

\begin{tabular}{|l|c|c|c|c|c|}
\hline \multicolumn{1}{|c|}{ Model } & $\begin{array}{c}\text { Sum of } \\
\text { Squares }\end{array}$ & df & $\begin{array}{c}\text { Mean } \\
\text { Squar } \\
\text { e }\end{array}$ & F & Sig. \\
\hline $\begin{array}{l}\text { Regres- } \\
\text { sion }\end{array}$ & 271.628 & 4 & 67.907 & $\begin{array}{c}7.12 \\
0\end{array}$ & $\begin{array}{c}.000 \\
\text { b }\end{array}$ \\
\hline Residual & 915.58 & 96 & 9.537 & & \\
\hline Total & $\begin{array}{c}1187.20 \\
8\end{array}$ & $\begin{array}{c}10 \\
0\end{array}$ & & & \\
\hline
\end{tabular}

Sumber: Data diolah

Hasil uji statistik F pada tabel 8 menunjukkan nilai $F$ adalah 7,120 dengan tingkat signifikansi 0,000 sehingga dapat disimpulkan lebih kecil dari 0,05 . Uji statistik $\mathrm{F}$ memenuhi kriteria fit dengan melihat nilai $F$ hitung sebesar 7,120. Nilai $F$ tabel didapat dari degrees of freedom (df) dengan signifikansi $\alpha=0,05$, dan df regresi $\left(\mathrm{n}_{1} / \mathrm{k}\right)=4$, df residual $\left(\mathrm{n}_{2}\right)=96$, yaitu $\mathrm{F}$ tabel $=2,47$ maka $\mathrm{F}$ hitung $>\mathrm{F}$ tabel $(7,120>2,47)$. Tabel 8 menunjukkan bahwa model regresi menunjukkan bahwa profesionalisme, risiko audit, tekanan anggaran waktu dan biaya audit secara simultan memiliki pengaruh terhadap kualitas audit.

Uji Signifikansi Individual

Hasil uji t disajikan dalam tabel 9.

Tabel 9. Hasil Uji Signifikansi Individual t

\begin{tabular}{|l|l|}
\hline Variabel & Sig. \\
\hline Kualitas Auditor (AQ) & .000 \\
\hline Profesionalisme (PF) & .013 \\
\hline Risiko Audit (AR) & .027 \\
\hline $\begin{array}{l}\text { Time Budget Pressure } \\
\text { (TBP) }\end{array}$ & .898 \\
\hline Audit Fee (AF) & .028 \\
\hline
\end{tabular}

Sumber: Data diolah

Variabel Profesionalisme (PF), Risiko Audit
(AR), dan biaya audit (AF) memiliki nilai signifikansi individual $t$ lebih kecil dari 0,05. Hasil ini dapat menunjukkan bahwa $\mathrm{Ha}_{1}, \mathrm{Ha}_{2}$, dan $\mathrm{Ha}_{4}$ diterima. Sedangkan Variabel tekanan anggaran waktu (TBP) memiliki nilai signifikansi sebesar 0,898 sehingga disimpulkan bahwa TBP tidak memiliki pengaruh terhadap kualitas audit. Berdasarkan pada pernyataan responden untuk pernyataan variabel TBP, rata-rata responden setuju bahwa anggaran waktu adalah keputusan dari atasan yang tidak dapat diganggu gugat. Hasil ini didukung dengan data bahwa nilai rata-rata jawaban responden untuk pernyataan tersebut senilai 4,13. Tekanan anggaran waktu ditentukan secara mutlak oleh atasan, sehingga baik pendek ataupun panjang, auditor tetap harus menyelesaikan tugas audit tepat waktu dan berkualitas. Persamaan regresi dalam penelitian ini sebagai berikut:

$\mathrm{AQ}=28,432+0,359 \mathrm{PF}-0,146 \mathrm{AR}+0,166 \mathrm{AF}+$ 0,012 TBP

Berdasarkan hasil uji t di tabel 9, koefisien regresi untuk variabel profesionalisme (PF) senilai 0,259 memiliki arti bahwa setiap penambahan atau kenaikan satu satuan profesionalisme, maka kualitas audit akan meningkat 0,259 atau 25,9\%. Koefisien regresi variabel risiko audit (AR) senilai 0,146 memiliki arti setiap terjadi pengurangan atau penurunan satu satuan risiko audit, maka akan menyebabkan terjadinya kenaikan terhadap kualitas audit sebesar 0,146 atau 14,6\%. Variabel risiko audit memiliki arah negatif yang artinya semakin rendah risiko audit, semakin meningkat kualitas audit yang dihasilkan.

Berdasarkan hasil uji $t$ di tabel 9, koefisien regresi variabel biaya audit $(\mathrm{AF})$ senilai 0,166 memiliki arti setiap penambahan atau kenaikan satu satuan biaya audit, maka akan menyebabkan terjadinya peningkatan terhadap kualitas audit sebesar 0,166 atau $16,6 \%$.

Berdasarkan hasil uji t pada tabel 9, koefisien regresi variabel tekanan anggaran waktu (TBP) senilai 0,012 yang memiliki arti setiap penambahan atau kenaikan satu satuan tekanan anggaran waktu, maka akan terjadi peningkatan Kualitas Audit sebesar 0,012 atau 1,2\%. Dikarenakan dari 101 responden, terdapat 56 responden atau sebesar $55,45 \%$ setuju dan 22 responden atau 21,78\% sangat setuju bahwa keefisienan waktu dalam pekerjaan sangat ditekankan sehingga menghasilkan kualitas audit yang tinggi. Terdapat 57 responden atau 
sebesar $56,44 \%$ setuju dan 24 responden atau sebesar $23,76 \%$ dari 101 responden sangat setuju bahwa anggaran waktu menjadi indikator atasan untuk menilai kinerja auditor. Hal ini menunjukkan bahwa tekanan anggaran waktu yang tinggi memberikan keefisienan waktu untuk auditor menghasilkan kualitas audit dan menjadi dasar penilaian kinerja oleh atasan, sehingga semakin efisien auditor melaksanakan tugas dan menghasilkan audit yang berkualitas maka semakin baik penilaian kinerja auditor oleh atasan, yang mendorong auditor untuk menghasilkan audit yang berkualitas walaupun dengan tekanan anggaran waktu yang tinggi.

\section{SIMPULAN}

Hasil pengujian menunjukkan bahwa profesionalisme, Risiko Audit, dan biaya audit berpengaruh terhadap kualitas audit. Variabel tekanan anggaran waktu tidak berpengaruh terhadap kualitas audit. Hasil ini berdasarkan data penelitian merupakan auditor yang memiliki pengalaman cukup dan berkompeten melaksanakan tugas, sehingga tekanan anggaran waktu tidak mempengaruhi auditor dalam menyelesaikan tugas tepat waktu.

Penelitian ini telah menunjukkan bahwa sejauh auditor tersebut melaksanakan prosedur audit dengan mengutamakan profesionalisme, mengidentifikasikan risiko audit yang akan terjadi, dan tanggung jawab terhadap klien yang ditunjukkan dari biaya audit yang tinggi, maka kualitas audit yang dihasilkan akan berkualitas baik, tidak melihat apakah auditor mengerjakan dengan waktu yang singkat atau panjang. Prosedur audit / standar audit telah dibuat dengan beaik, maka auditor yang memiliki pengalaman cukup akan mengetahui dan menentukan prosedur audit yang tepat sehingga time budget pressure tidak berpengaruh.

Keterbatasan dalam penelitian ini, yaitu berdasarkan hasil pengujian statistik, variabel independen yaitu profesionalisme, risiko audit, tekanan anggaran waktu dan biaya audit hanya mampu menjelaskan kualitas audit (variabel dependen) sebesar 19,7\%, sebesar 80,3\% dijelaskan oleh variabel lain. Sehingga disarankan peneliti selanjutnya menambahkan variabel independen lainnya seperti independensi, kompetensi, akuntabilitas, pengalaman kerja auditor, dan etika profesi.

\section{REFFERENCES}

Arens, A. A., Elder, R. J. dan Beasley, M. S. (2017). Auditing and Assurance Services: An Integrated
Approach. England: Pearson.

Ariningsih, P. S. dan Mertha, I. M. (2017). Pengaruh Independensi, Tekanan Anggaran Waktu, Risiko Audit, Dan Gender Pada Kualitas Audit. E-Jurnal Akuntansi Universitas Udayana, 18(2), 1545-1574.

Chung, H. H. dan Wynn, J. P. (2014). Corporate Governance, Directors' And Officers' Insurance Premiums and Audit Fees. Managerial Auditing Journal, 29(2), 173-195.

Deli, L., Fatma, A., dan Syarif, F. (2015). FaktorFaktor yang Mempengaruhi Kualitas Audit dengan Etika Auditor Sebagai Moderating Variabel. Jurnal Riset Akuntansi dan Bisnis, 15(1), 1-17.

Dhimadhanu, R. (2016). Pengaruh Asimetri Informasi, Fee Audit, dan Tenur Audit Terhadap Kualitas Audit Pada Perusahaan Perusahaan Non-Keuangan yang Terdaftar Pada LQ45. Gema Ekonomi Jurnal Fakultas Ekonomi, 5(1), 43-53.

Dwimilten, E., dan Riduwan, A. (2015). FaktorFaktor yang Mempengaruhi Kualitas Audit. Jurnal Ilmu dan Riset Akuntansi, 4(4), 1-20.

Fietoria dan Manalu, E. S. (2016). Pengaruh Profesionalisme, Independensi, Kompetensi, dan Pengalaman kerja Terhadap Kualitas Audit di Kantor Akuntan Publik Bandung. Journal of Accounting and Business Studies, 1(1), 20-38.

Futri, P. S. dan Juliarsa, G. (2014). Pengaruh Independensi, Profesionalisme, Tingkat Pendidikan, Etika Profesi, Pengalaman, dan Kepuasan Kerja Auditor Terhadap Kualitas Audit pada Kantor Akuntan Publik di Bali. EJurnal Akuntansi Universitas Udayana, 8(1), 4158.

Gaol, M. B. L. (2018). The Influence of Audit Time Budget Pressure on Reduced Audit Quality Behavior. Journal of Accounting Research, Organization and Economics, 1(1), 57-64.

Ghozali, I. (2018). Aplikasi Analisis Multivariate dengan program IBM SPSS 25. Semarang: Badan Penerbit Universitas Diponegoro.

Gundry, L. C. dan Liyanarachchi, G. A. (2007). Time Budget Pressure, Auditors' Personality Type, And The Incidence Of Reduced Audit Quality Practices. Pacific Accounting Review, 19(2), 125-152.

Harish, N. M., Rahayu, S. dan Aminah, W. (2017). Pengaruh Fee Audit, Kompetensi, Auditor, dan Perubahan Kewenangan Terhadap Motivasi Auditor (Survey Auditor Kantor Akuntan Publik di Bandung). E-Proceeding of Management 4(3), 2791-2795. 
Hajering., Suun, M. dan Muslim. (2019). Moderating Ethics Auditors Influence of Competence, Accountability on Audit Quality. Jurnal Akuntansi, 23(3), 468-481.

Hapsoro, D. dan Santoso, T. R. (2018). Does Audit Quality Mediate the Effect of Auditor Tenure, Abnormal Audit Fee and Auditor's Reputation on Giving Going Concern Opinion. International Journal of Economics and Financial Issues, 8(1), 143-152.

Hinarno, E. dan Osesoga, M. S. (2016). Pengaruh Kualitas Auditor, Kondisi Keuangan, Kepemilikan Perusahaan, Disclosure, Pertumbuhan Perusahaan, dan Debt Defaultterhadap Penerimaan Opini Going Concern. Ultima Accounting, 8(2), 89-110.

Idawati, W. (2018). Analisis Karakteristik Kunci yang Mempengaruhi Kualitas Audit. Jurnal Akuntansi, 22(1), 33-50.

Ikatan Akuntan Indonesia. (2018). Standar Akuntansi Keuangan. Jakarta: IAI.

Institut Akuntan Publik Indonesia. (2018). Kode Etik Profesi Akuntan Publik. Jakarta: IAPI.

Julianto, I. K. A., Yadnyana, I. K. dan Suputra, I. D. G. D. (2016). Pengaruh Audit Fee, Perencanaan Audit, dan Risiko Audit terhadap Kualitas Audit pada Kantor Akuntan Publik di Bali. EJurnal Ekonomi dan Bisnis Universitas Udayana, 5(12), 4029-4056.

Kartika, T. P. D. dan Nahumury, J. (2014). The effect of litigation risks to earnings management using auditquality as moderating variable. Journal of Economics, Business, and Accountancy Ventura, 17(2), 303 - 312.

Knechel, W. R., Krishnan, V. G., Pevzner, M. N., Shefchik, L. B. dan Velury, U. (2013). Audit Quality: Insights from the Academic Literature. Auditing: A Journal of Practice \& Theory, 32(1), 166.

Kuntari ,Y., Chariri A. dan Nurdhiana. (2017). The Effect of Auditor Ethics, Auditor Experience, Audit Fees and Auditor Motivation on Audit Quality. SIJDEB, 1(2), 203-218.

Lee, D. dan Sukartha, I. M. (2017). Fee Audit sebagai Pemoderasi Pengaruh Auditor Switching dan Audit Tenurepada Kualitas Audit. E-Jurnal Ekonomi dan Bisnis Universitas Udayana, 18(2), 1455-1484.

Majalah ICT. (2017). Ada Apa Ketika Afiliasi Ernst \& Young Salah Audit Keuangan Indosat?. Didapat dari https:/ / www.majalahict.com/ada-apa-ketika- afiliasi-ernst-young-salah-audit-keuanganindosat/, 28 September 2019, pukul 10.42 WIB.

Mindak, M. dan Heltzer, W. (2011). Corporate Environmental Responsibility and Audit Risk, Managerial Auditing Journal, 26(8), 697-733.

Oklivia, dan Marlinah, A. (2014). Pengaruh Kompetensi, Independensi, dan Faktor-Faktor dalam Diri Auditor Lainnya Terhadap Kualitas Audit. Jurnal Bisnis dan Akuntansi, 16(2), 143157.

Prabhawanti, P. dan Widhiyani, N. L. S. (2018). Pengaruh Besaran Fee Audit dan Independensi Terhadap Kualitas Audit dan Etika Profesi Auditor Sebagai Moderasi. E-Jurnal Akuntansi Universitas Udayana, 24(3), 2247-2273.

Pramaswaradana, I. G. N. I., dan Astika, I. B. P. (2017). Pengaruh Audit Tenure, Audit Fee, Rotasi Auditor, Spesialisasi Auditor, dan Umur Publikasi Pada Kualitas Audit. E-Jurnal Akuntansi Universitas Udayana, 19(1), 168-194.

Pramesti, I. G. A. R., dan Wiratmaja , I. D. N. (2017). Pengaruh Fee Audit, Profesionalisme pada Kualitas Audit dengan Kepuasan Kerja sebagai Pemediasi. E-Jurnal Akuntansi Universitas Udayana, 18(1), 616-645.

Pratama, I. M. I. dan Merkusiwati, N. K. L. A. (2014). Pengaruh Time Budget Pressure, Risiko Kesalahan Audit, dan Masa Perikatan Audit Terhadap Kualitas Audit Pada Kantor Akuntan Publik Di Daerah Bali. E-Jurnal Akuntansi Universitas Udayana, 8(3), 353-370.

Public Company Accounting Oversight Board (PCAOB). (2017a). Order Instituting Disciplinary Proceedings, Making Findings, and Imposing Sanctions.. Didapat dari, https:/ / pcaobus.org/Enforcement/Decisions / Documents/105-2017-002-EY-Indonesia.pdf., 26 September 2019, pukul 16:30 WIB.

Public Company Accounting Oversight Board. (2017b). PCAOB Announces \$1 Million Settlement with Indonesian Member of Ernst $\mathcal{E}$ Young Network for Audit Failure, Noncooperation, and Violations of Quality Control Standards. Didapat dari

https://pcaobus.org/News/Releases/Pages/E Y-Indonesia-enforcement-2-9-16.aspx., 26 September 2019, pukul 17.34 WIB.

Rahmina, L. Y. dan Agoes, S. (2014). Influence of auditor independence, audit tenure, and audit fee on audit quality of members of capital market accountant forum in Indonesia. Procedia - Social and Behavioral Sciences, 164, 324-331. 
Safaroh, I., Susilawati, R. A. E. dan Halim, A. (2016). Pengaruh Independensi, Profesionlisme, Rotasi KAP, dan Anggaran Waktu terhadap Kualitas Audit (Studi Empiris Kantor Akuntan Publik di Wilayah Kota Malang). Jurnal Riset Mahassiwa Akuntansi, 4(1), 1-15.

Skinner, D. J. dan Srinivasan, S. (2012). Audit Quality and Auditor Reputation: Evidence from Japan. The Accounting Review, 87(5), 1-15.

Suardinatha, M. H., dan Wirakusuma, M. G. (2016). Pengaruh Independensi dan Profesionalisme Terhadap Kualitas Audit dengan Kepuasan Kerja Sebagai Variabel Pemoderasi. E-Jurnal Akuntansi Universitas Udayana, 17(3), 2503-2530.

Sun, J. dan Liu, G. (2011). Client-Specific Litigation Risk And Audit Quality Differentiation. Managerial Auditing Journal, 26(4), 300-316.

Suryo, M. (2017). Pengaruh Time Budget Pressure dan Risiko Audit terhadap Kualitas Audit (Survey pada Auditor di Kantor Akuntan Publik di Bandung). Riset Akuntansi dan Keuangan, 5(1), 148-160.

Svanberg, J., dan Ohman, P. (2013). Auditors' time Pressure: Does Ethical Culture Support Audit Quality?. Managerial Auditing Journal, 28(7), 572-591.

Whittington, O. R. dan Pany, K. (2016). Principles of Auditing \& Assurance Services 20th Edition. New York: McGRAW-HILL International Edition.

Yandari, A. D., dan Sudaryati, E. (2017). How Decision Making To The Audit Fee, Audit Committee On A Audit Quality. Jurnal Akuntansi Universitas Jember, 15(2), 45-51.

Zam, D. R. P. dan Rahayu, S. (2015). Pengaruh Tekanan Anggaran Waktu (Time Budget Pressure), Fee Audit, dan Independensi Auditor terhadap Kualitas Audit (Studi Kasus Pada Kantor Akuntan Publik di Wilayah Bandung). E-Proceeding of Management, 2(2), 1800-1807. 